\title{
Bat Predation by a Cuban Treefrog (Osteopilus septentrionalis, Hylidae) and a Summary of Bat Predation by West Indian Amphibians and Reptiles
}

\author{
Carlos A. Mancina ${ }^{1}$, Leticia Mas Castellanos ${ }^{2}$, and Tomás M. Rodríguez-Cabrera ${ }^{3}$ \\ ${ }^{1}$ División de Zoología, Instituto de Ecología y Sistemática, La Habana, CP 11900, Cuba (mancina@ecologia.cu) \\ ${ }^{2}$ Centro de Estudios y Servicios Ambientales de Villa Clara, Villa Clara, Cuba (leticia@cesam.vcl.cu) \\ 3Jardín Botánico de Cienfuegos, Cienfuegos, CP 59290, Cuba (tomasmichel.rodriguez@gmail.com)
}

$\mathrm{T}^{\mathrm{T}}$ he West Indian treefrog genus Osteopilus comprises eight species native to some Bahamian islands, Cuba, Jamaica, and Hispaniola (Meshaka 2001; Henderson and Powell 2009). These frogs are opportunistic predators, consuming a high diversity of invertebrates and smaller vertebrates (Henderson and Powell 2009; Kaiser et al. 2016). The Cuban Treefrog (Osteopilus septentrionalis Duméril and Bibron 1841; Fig. 1) is native to the Bahamas, the Cuban Archipelago, and the Cayman Islands, but has been widely introduced to several Lesser Antillean islands, Puerto Rico, Hawaii, and mainland Florida (Henderson and Breuil 2012; Frost 2015), where it has become an invasive species (Meshaka 2001). In Cuba, this species is widely distributed and occupies a wide range of habitats (Díaz and Cádiz 2008; Rivalta et al. 2014). Its diet comprises a variety of invertebrates, including insects, arachnids, crustaceans, and gastropods, but it also is known to consume conspecifics, other species of frogs, and lizards (Meshaka 1996; Henderson and Powell 2009; Armas 2014; Kaiser et al. 2016).

Compared to non-volant mammals of similar size, bats face few predators (Altringham 1996; Lima and O'Keefe 2013). Furthermore, predation on bats by amphibians is rare and infrequently documented in the literature (Mikula 2015). Herein, we report an event of bat predation by a Cuban Treefrog.

In January 2016, we observed a large adult female Cuban Treefrog (nearly $130 \mathrm{~mm} \mathrm{SVL)} \mathrm{eating} \mathrm{a} \mathrm{bat} \mathrm{at} \mathrm{dusk} \mathrm{in} \mathrm{a} \mathrm{house}$ at "Reparto Universitario" $\left(22^{\circ} 26^{\prime} 00.05^{\prime \prime N},-79^{\circ} 54^{\prime} 28.00 " \mathrm{~W}\right.$; reference datum: WGS84), Santa Clara, Villa Clara Province, in central Cuba. The frog was on a concrete floor swallowing a bat headfirst (Fig. 2A); induced regurgitation (Fig. 2B) revealed an adult male Pallas's Mastiff Bat (Molossus molossus, Molossidae; $12 \mathrm{~g}$ body mass). The lack of rigor mortis suggested that the bat probably was alive when captured by the frog.
Pallas's Mastiff Bats (Fig. 3), like most molossids, have narrow wings and a high wing load (Norberg and Rayner 1987), limiting their capacity to lift off from the ground,

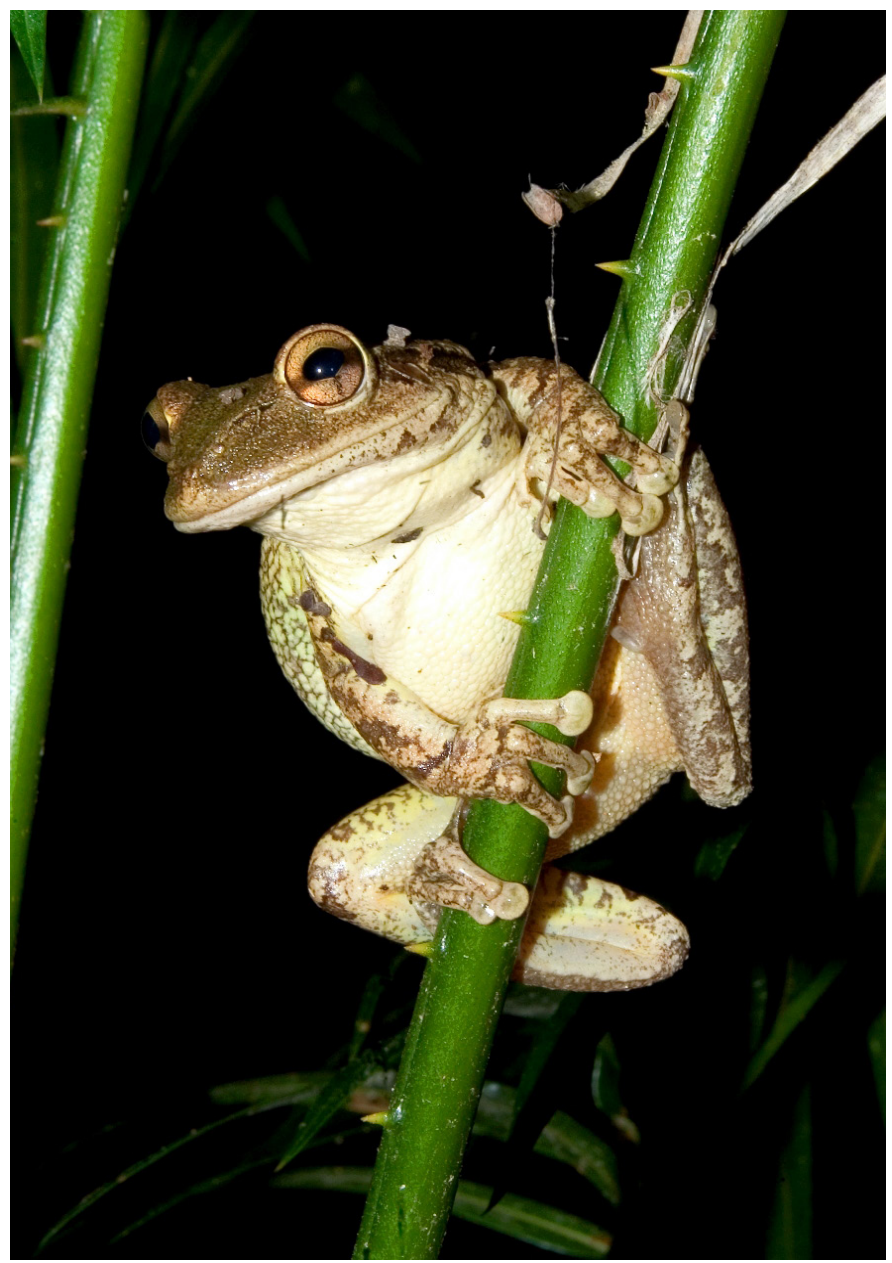

Fig. 1. Adult female Cuban Treefrog (Osteopilus septentrionalis). Photograph (C) C.A. Mancina. 
which increases their vulnerability to predation by frogs (or other opportunistic predators such as cats) when on the ground (or floor). Both O. septentrionalis and M. molossus occur throughout Cuba and frequently use buildings as foraging sites and diurnal retreats (Silva 1979; Díaz and Cádiz 2008). The fact that both are most frequently encountered

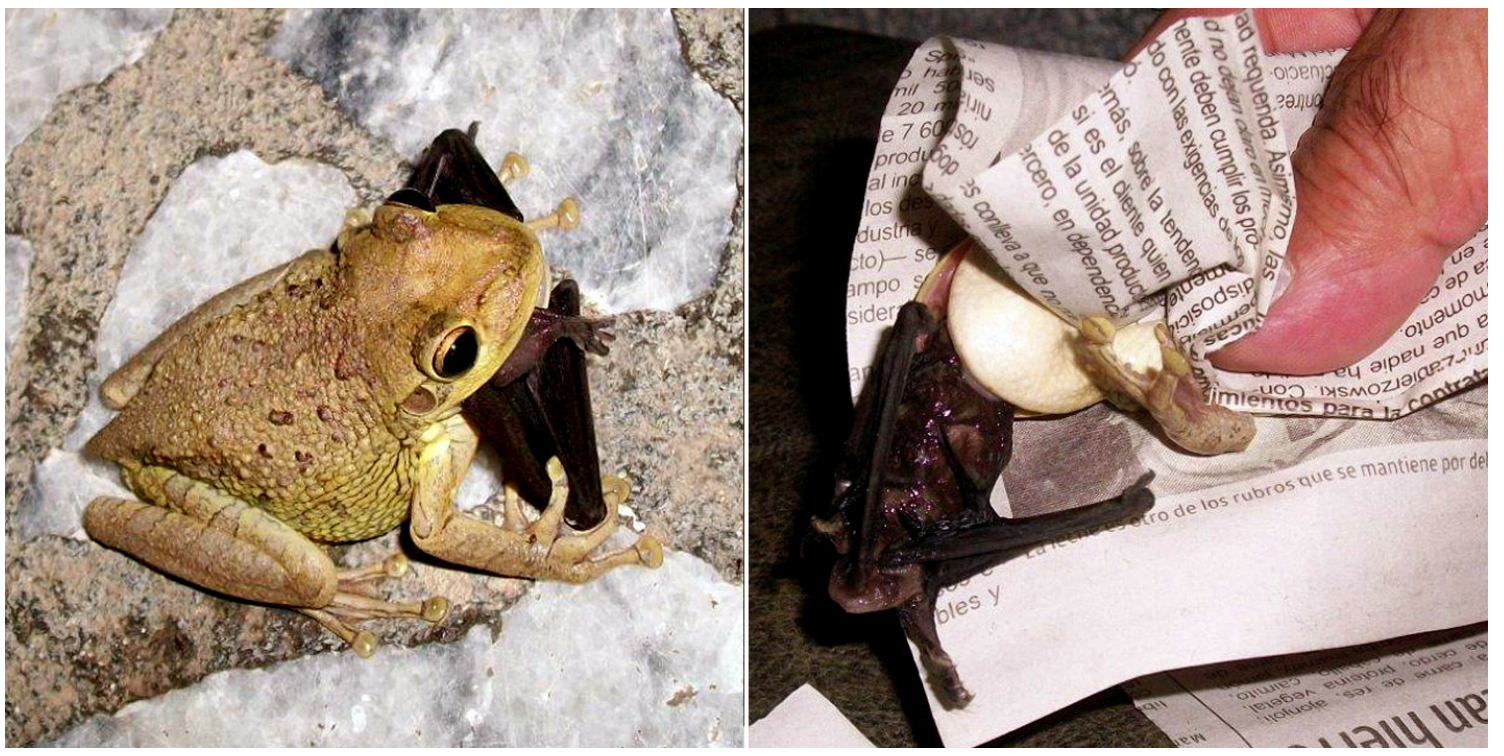

Fig. 2. Adult female Cuban Treefrog (Osteopilus septentrionalis; Hylidae) eating a Pallas’s Mastiff Bat (Molossus Molossus; Molossidae). Photographs (C) Leticia Mas Castellanos.

Table 1. Amphibians and reptiles reported as bat predators in the West Indies. References marked with an asterisk $\left(^{*}\right)$ were not examined but were cited in Henderson and Powell (2009).

\begin{tabular}{|c|c|c|c|}
\hline Predator & Bat species & Island & Sources \\
\hline \multicolumn{4}{|l|}{ AMPHIBIA: ANURA } \\
\hline Leptodactylus fallax (Leptodactylidae) & Unidentified & Dominica & Lescure $(1979)^{*}$ \\
\hline Lithobates catesbeianus (Ranidae) & Unidentified (bones in stomach) & Cuba & Vogel $(1965)^{*}$ \\
\hline Osteopilus septentrionalis (Hylidae) & $\begin{array}{l}\text { Eptesicus fuscus } \\
\text { Molossus molossus }\end{array}$ & $\begin{array}{l}\text { Cuba } \\
\text { Cuba }\end{array}$ & $\begin{array}{l}\text { Silva (1979) } \\
\text { This paper }\end{array}$ \\
\hline Gekko gekko (Gekkonidae) & Molossus molossus, Tadarida brasiliensis & Martinique & Breuil $(2009)^{*}$ \\
\hline Boa orophias (Boidae) & Brachyphylla cavernarum & Saint Lucia & Arendt and Anthony (1986) \\
\hline Boa nebulosa (Boidae) & Brachyphylla cavernarum & Dominica & Angin (2014) \\
\hline Chilabothrus angulifer (Boidae) & $\begin{array}{l}\text { Brachyphylla nana, Mormoops blainvillei, } \\
\text { Phyllonycteris poeyi, Erophylla sezekorni, } \\
\text { unidentified species }\end{array}$ & Cuba & $\begin{array}{l}\text { Hardy (1957b), Sheplan and } \\
\text { Schwartz (1974) Mancina (2011), } \\
\text { Rodríguez-Cabrera et al. (2015) }\end{array}$ \\
\hline Chilabothrus subflavus (Boidae) & $\begin{array}{l}\text { Artibeus jamaicensis, unidentified } \\
\text { species }\end{array}$ & Jamaica & $\begin{array}{l}\text { Prior and Gibson (1997), Koenig } \\
\text { and Schwartz (2003), Dávalos and } \\
\text { Eriksson (2004) }\end{array}$ \\
\hline Cubophis cantherigerus (Dipsadidae) & $\begin{array}{l}\text { Phyllonycteris poeyi, unidentified } \\
\text { species }\end{array}$ & Cuba & $\begin{array}{l}\text { Hardy (1957a), Henderson and } \\
\text { Sajdak (1996) }\end{array}$ \\
\hline Bothrops lanceolatus (Viperidae) & Unidentified & Martinique & Pinchon $(1967)^{*}$ \\
\hline
\end{tabular}



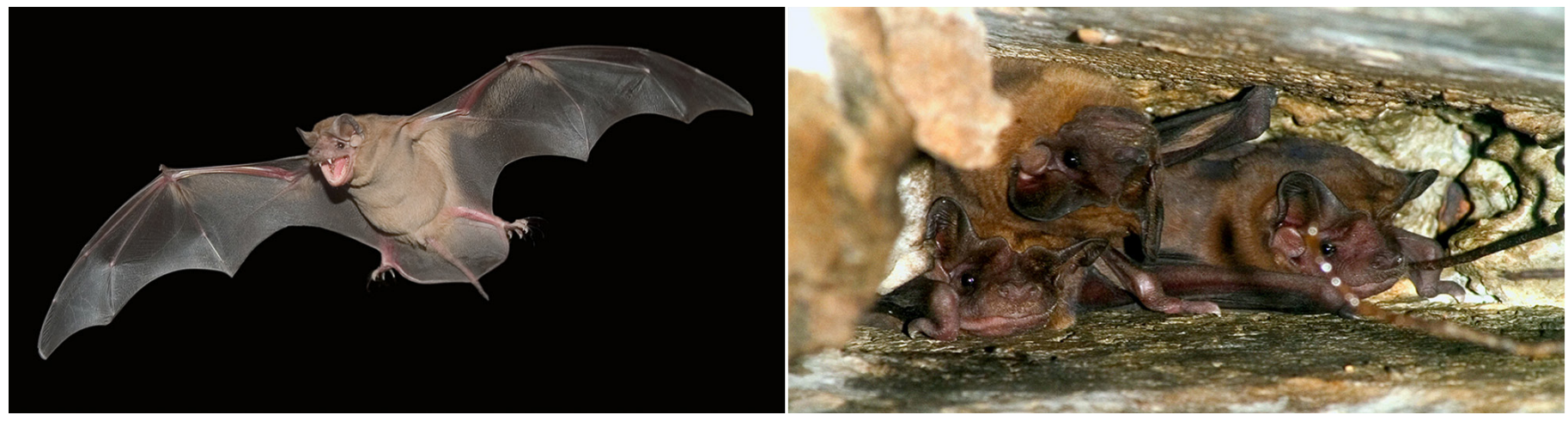

Fig. 3. Flying Pallas's Mastiff Bats (Molossus molossus, left) and a cluster of individuals roosting in a building crevice (right). Photographs (C) C.A. Mancina.

in urban environments suggests that similar events may be relatively frequent although rarely observed and documented.

In a recent review paper, Mikula (2015) compiled 37 cases of bat predation by amphibians, listing 14 frog species preying on bats and 16 bat species as prey. Mikula (2015) did not include any frogs in the genus Osteopilus, although Silva (1979) identified a Big Brown Bat (Eptesicus fuscus, Vespertilionidae) taken from the stomach of an O. septentrionalis found in a toilet at a tourist village in central Cuba. Also in Cuba, Vogel (1965) recorded the presence of bones of an unidentified bat in the stomach of an invasive American Bullfrog (Lithobates catesbeianus, Ranidae).

The most common predators of bats in the Antillean islands are nocturnal avian raptors (e.g., Hernández and Mancina 2013) and falconids (e.g., Rodríguez-Durán and Lewis 1985); however, at least 11 species of amphibians and reptiles are known to prey on bats (Table 1). With the exception of some boids of the genus Chilabothrus that regularly feed on bats (e.g., Rodríguez-Cabrera et al. 2015), these are best considered opportunistic bat predators. In the Greater Antilles, caves with high aggregations of bats are abundant, and bats there are potentially vulnerable to predators, particularly during emergence. Eastern Giant Toads (Peltophryne peltocephala) have been observed at Cayo Caguanes, in northcentral Cuba, posted at dusk near the openings of caves that shelter large colonies of Gervais's Funnel-eared Bats (Nyctiellus lepidus, Natalidae; $2.5 \mathrm{~g}$ body mass), apparently waiting for emerging bats, although predation has not been confirmed (H. Vela, pers. comm.). Richards and Hall (2012) observed similar behavior in Australian caves by the invasive Cane Toad (Rhinella marina), a species widely introduced in the West Indies (albeit not in Cuba; Powell et al. 2011).

\section{Acknowledgements}

We thank Humberto Vela (Sociedad Espeleológica de Cuba) for sharing unpublished observations. We also acknowledge Susan E. Koenig (Jamaica) and Alberto R. Puente-Rolón (Puerto Rico) for providing literature references.

\section{Literature Cited}

Angin, B. 2014. Bat predation by the Dominica Boa (Boa nebulosa). Caribbean Herpetology 51: 1-2.

Altringham, J.D. 1996. Bats: Biology and Behaviour. Oxford University Press, Oxford, UK.

Arendt, W.J. and D. Anthony. 1986. Bat predation by the St. Lucia Boa (Boa constrictor orophias). Caribbean Journal of Science 22: 219-220.

Armas, L.F. de. 2014. Depredación de Centruroides gracilis (Latreille, 1804) (Scorpiones: Buthidae) por Osteopilus septentrionalis Duméril and Bibron, 1841 (Anura: Hylidae). Revista Ibérica de Aracnología 24: 125-126.

Breuil, M. 2009. The terrestrial herpetofauna of Martinique: Past, present, future. Applied Herpetology 6: 123-149.

Dávalos, L.M. and R. Eriksson. 2004. Epicrates subflavus. Foraging behavior. Herpetological Review 35: 66.

Díaz, L.M. and A. Cádiz 2008. Guía taxonómica de los anfibios de Cuba. ABC Taxa 4: 1-294 + CD.

Frost, D.R. 2015. Amphibian Species of the World: An Online Reference. Version 6.0. American Museum of Natural History, New York, USA. <http://research. amnh.org/herpetology/amphibia/index.html .

Hardy, J.D., Jr. 1957a. A note on the feeding habits of the Cuban Racer, Alsophis angulifer (Bibron). Copeia 1957: 49-50.

Hardy, J.D., Jr. 1957b. Bat predation by the Cuban Boa, Epicrates angulifer Bibron. Copeia 1957: 151-152.

Henderson, R.W. and M. Breuil. 2012. Lesser Antilles, pp. 150-161. In: R. Powell and R.W. Henderson (eds.), Island lists of West Indian amphibians and reptiles. Bulletin of the Florida Museum of Natural History 51: 87-168.

Henderson, R.W. and R. Powell. 2009. Natural History of West Indian Amphibians and Reptiles. University Press of Florida, Gainesville, Florida.

Henderson, R.W. and R.A. Sajdak. 1996. Diets of West Indian racers (Colubridae: Alsophis): Composition and biogeographic implications, pp. 227-338. In: R. Powell and R.W. Henderson (eds.), Contributions to West Indian Herpetology: A Tribute to Albert Schwartz. Contributions to Herpetology, volume 12. Society for the Study of Amphibians and Reptiles, Ithaca, New York.

Hernández Muñoz, A. and C.A. Mancina. 2011. La dieta de la Lechuza (Tyto alba) (Aves: Strigiformes) en hábitat naturales y antropógenos de la región central de Cuba. Revista Mexicana de Biodiversidad 82: 309-318.

Kaiser, H., M.C. Chamberlain, T. Edwards, J.R. Nuñez, T.M. Rodríguez-Cabrera, and J. Torres. 2016. Cannibalism in Cuba: First direct observations of Cuban Treefrogs (Osteopilus septentrionalis, Hylidae) feeding on conspecifics in their native habitat, with a brief review of anurophagy and cannibalism in treefrogs. Reptiles \& Amphibians 23: 21-27.

Koenig, S.E. and M. Schwartz. 2003. Epicrates subflavus (Jamaican Yellow Boa). Diet. Herpetological Review 34: 363-364.

Lescure, J. 1979. Étude taxinomique et éco-éthologique d'un Amphibien des petites Antilles: Leptodactylus fallax Muller, 1926 (Leptodactylidae). Bulletin du Muséum National d'Histoire Naturelle, Paris 4, serie 1, section A, 3: 757-774.

Lima, S.L. and J.M. O'Keefe. 2013. Do predators influence the behaviour of bats? Biological Reviews 88: 626-644. 
Mancina, C.A. 2011. Introducción a los murciélagos, pp. 122-133. In: R. BorrotoPáez and C.A. Mancina (eds.), Mamíferos en Cuba. UPC Print, Vaasa, Finland.

Meshaka, W.E. 1996. Diet and the colonization of buildings by the Cuban Treefrog, Osteopilus septentrionalis (Anura: Hylidae). Caribbean Journal of Science 32: 59-63.

Meshaka, W.E. 2001. The Cuban Treefrog in Florida. University of Florida Press, Gainesville, Florida.

Mikula, P. 2015. Fish and amphibians as bat predators. European Journal of Ecology 1: 71-80.

Norberg, U.M. and J.M.V. Rayner. 1987. Ecological morphology and flight in bats (Mammalia; Chiroptera): Wing adaptations, flight performance, foraging strategy and echolocation. Philosophical Transactions of the Royal Society of London. Series B, Biological Sciences 316: 335-427.

Pinchon, R. 1967. Quelques aspects de la nature aux Antilles. Imprimeurs à Caen, Fort-de-France, Martinique.

Powell, R., R.W. Henderson, M.C. Farmer, M. Breuil, A.C. Echternacht, G. van Buurt, C.M. Romagosa, and G. Perry. 2011. Introduced amphibians and reptiles in the Greater Caribbean: Patterns and conservation implications, pp. 63-143. In: A. Hailey, B.S. Wilson, and J.A. Horrocks (eds.), Conservation of Caribbean Island Herpetofaunas. Volume 1: Conservation Biology and the Wider Caribbean. Brill, Leiden, The Netherlands.

Prior, K.A. and R.C. Gibson. 1997. Observations on the foraging behavior of the Jamaican Boa, Epicrates subflavus. Herpetological Review 28: 72-73.

Puente-Rolón, A.R. 2012. Reproductive ecology, fitness and management of the Puerto Rican Boa (Epicrates inornatus, Boidae). Unpublished Ph.D. Thesis, University of Puerto Rico, Río Piedras.

Puente-Rolón, A.R. and F.J. Bird-Picó. 2004. Foraging behavior, home range, movements and activity patterns of Epicrates inornatus (Boidae) at Mata de
Plátano Reserve in Arecibo, Puerto Rico. Caribbean Journal of Science 40: 343-352.

Richards, G. and L. Hall. 2012. A Natural History of Australian Bats: Working the Night Shift. CSIRO Publishing, Collingwood, Australia.

Rivalta, V., L. Rodríguez-Schettino, C.A. Mancina, and M. Iturriaga. 2014. Amphibians of Cuba: checklist and geographic distributions. Smithsonian Herpetological Information Service 145: 1-50.

Rodríguez-Cabrera, T.M., J. Torres, and R. Marrero. 2015. At the lower size limit of snakes preying on bats in the West Indies: The Cuban Boa, Chilabothrus angulifer (Boidae). Reptiles \& Amphibians 22: 8-15.

Rodríguez-Durán, A. 1996. Foraging ecology of the Puerto Rican Boa (Epicrates inornatus): Bat predation, carrion feeding and piracy. Journal of Herpetology 30: 533-536.

Rodríguez-Durán, A. and A.R. Lewis. 1985. Seasonal predation by Merlins on Sooty Mustached Bats in western Puerto Rico. Biotropica 17: 71-74.

Rodríguez, G. and D.P. Reagan. 1984. Bat predation by the Puerto Rican Boa (Epicrates inornatus). Copeia 1984: 219-220.

Silva Taboada, G. 1979. Los murciélagos de Cuba. Editorial Academia, La Habana, Cuba.

Sheplan, B.R. and A. Schwartz. 1974. Hispaniolan boas of the genus Epicrates (Serpentes: Boidae) and their Antillean relationships. Annals of Carnegie Museum of Natural History 45: 57-143.

Vogel, Z. 1965. Herpetologische Beobachtungen auf Kuba (IV). Froschfang auf Kuba. Aquarien Terrarien 12: 420-422.

Wiley, J.W. 2003. Habitat association, size, stomach contents and reproductive conditions of Puerto Rican Boas (Epicrates inornatus). Caribbean Journal of Science 39: 189-194. 